\title{
Communication Quality as a Determinant Influencing Customer Behavior in the Terms of E-Commerce Subjects in Visegrad Group Countries
}

\author{
Mgr. Richard Fedorko, PhD \\ Faculty of management - University of Prešov; Email: Richard.Fedorko@unipo.sk \\ Doc. PhDr. Radovan Bačík, PhD. MBA \\ Faculty of management - University of Prešov; Email: Radovan.Bacik@unipo.sk
}

PhDr. Igor Fedorko

Faculty of management - University of Prešov; Email: Igor.Fedorko@smail.unipo.sk

\section{Doi:10.5901/mjss.2016.v7n1p184}

\begin{abstract}
The aim of the paper was to define specific aspects of e-commerce subjects in Visegrad group countries according to their customers. The paper summarized the current state of e-business and e-commerce issue in the Czech Republic, Hungary, Poland and Slovakia. The study contained data obtained from the data analysis of 5,228,127 evaluations of 9,260 e-shops. The main focus was given to customer's overall degree of willingness to recommend an e-shop in relation to quality of communication with a customer. The contribution of the study lies in the revelations of the links between customer behavior and communication quality of e-commerce subjects and last but not least, in a better understanding of customer needs.
\end{abstract}

Keywords: e-business, e-commerce, Visegrad group, B2C, customer satisfaction

\section{Introduction \& Theory}

The fast development of communication and information technologies in business activities is the most significant longterm trend in the business world (Rust, Lemon 2001; Bauer et al. 2006). Continued progress in internet technology and related applications allow consumers to interact with different companies and institutes (Gavurová, 2012). More and more organizations invest substantially in online customer - centric solutions and technologies in order to increase its share on the online market (Šoltés and Gavurová 2013, 2015). As observed by Vila and Kuster (2011), companies devote a significant part of this effort to improve the visual and the design of their corporate websites and also the quality of customers' experience. Further research in this area is usually focused on exploring the relationship between consumers' behavior and websites' design (Gburova and Matusikova 2014; Kwon, Kim, Lee 2002; Michalski 2014; Moss, Gunn, Heller 2006; Dorčák et. al. 2014, Bem et al. 2014; Szczygiel et al. 2015; Raisova et al. 2014).

The recent years has seen a continuous growth of the Internet and apps that represent a new way for reaching and retaining customers by offering new services and products (Tan, Teo, 2000). When using such apps it is in the interest of both parties (organizations and consumers) to monitor and analyze their perception and the main reasons for consumers to express their willingness to adapt these technologies (Lee 2009; Liao, Cheung 2002).

Adolphs and Winkelmann state in their work, dealing with personalization in e-commerce (2010), views of various authors on the role of personalization in e-commerce. The authors state the definitions that can be divided into two categories. The first category indicates a close relationship between recommending and personalization of content, acquisition and user data processing or identifies them indirectly. The second category extends the scope of the term and focuses on the goals of personalization. Recognizing the user is one of the most widespread and simplest methods of personalization. During communication with the user the system collects data through, for example, cookies. This may be a device, a browser, an operating system, a screen resolution, language settings and geographic location of the user. This data can be immediately used when communicating with the user or only at his next visit to the site.

Based on obtained information the system adapts its behavior in various ways. Recognizing the user is typically not a separate function, but is a part of a more comprehensive personalized solution (Muller 2014). A comfort system - 
recommendation types can be divided into personalized and non-personalized. An example of non-personalized recommendation, which is usually encountered outside the web environment, may be a list of top selling book titles and so on. Due to the simplicity of the problem available literature deals almost exclusively with personalized recommendation. In order to provide personalized recommendation the recommendation systems need to obtain data on the behavior and preferences of the particular user or user segment. In doing so the systems use knowledge from different fields of informatics such as data mining, machine learning, information retrieval and interaction human computer (Ricci 2011).

The aim of the paper is to provide the information about the state of customer satisfaction of the business model B2C subjects in Visegrad group countries, namely Slovakia, the Czech Republic, Poland and Hungary.

\section{Methodology}

The aim of the analysis was the post-purchase evaluation of e-commerce subjects of the business model B2C processed on the basis of the evaluations within online portals. The first phase of the research was the identification of the online portals focused on post-purchase evaluation of e-shops in Visegrad group countries. The key factor for the selection of the suitable portal was the need of the highest match of variables evaluated by customers or the highest match of evaluated criteria monitored by online portal. One online portal per research country was identified, i.e. Heureka.sk, Heureka.cz, Arukereso.hu and Ceneo.pl. Interesting finding was that all four online portals are managed by Allegro Group operating in 25 countries around the world, but mainly in the Central and Eastern Europe including Slovakia, Czech Republic, Hungary, Bulgaria, Poland, Ukraine, Russia, Romania, Baltic States and Turkey. Allegro Group's (2015) activities are mainly targeted on e-commerce platforms for consumers enabling effortless and secure online transactions in segments like marketplaces, classifieds, payments and retail. Allegro Group (2015) operates and owns over one hundred e-commerce associated websites. Most of this e-commerce websites are leaders in respective countries thanks to strong focus on regional consumers' needs. Actually Allegro Group (2015) employs over 6500 Europeans directly. In a group of selected online portals, the best match of the evaluated variables had Heureka.sk and Heureka.cz. Moreover, online portal Heureka.sk had the most evaluated criteria, as well as the most unique evaluated criteria within research countries.

The next step of the analysis was the identification of the suitable subjects - e-shops for the data collection represented in the form of customers experience evaluations. The method of automatic data collection was used by a script of programming language PHP 5.4.25, MySQL 5.5.36 databases and web server Apache 2.4.7. In addition, four individual scripts, adapted to source code of the selected online portals, were created for the identification and database recording of the variables, such as e-shop name and url linked to an e-shop subpage (profile) containing customer' evaluations, all within the source code of the subpages summarizing the evaluated e-shops. The realization phase was performed in May 2013. There were 15194 e-shops identified as follows: SK: 1123 (7,39 \%), CZ: 5636 (37,09 \%), PL: 7 $437(48,95 \%), \mathrm{HU}: 998(6,57 \%)$. The third phase of the analysis was the data collection of the observed variables (evaluations) within online portals of the identified e-shops. From the total number of identified e-shop, only suitable subjects were chosen for the further deeper analysis. To be more concrete, the e-shops with customers evaluations and e-shops not identified as inactive were analyzed. The method of automatic data collection by script of programming language PHP, MySQL databases and web server Apache were used, as well. This phase of analysis needed considerable effort, because diversity of the observed online portals, concretely the structures of e-shops' profiles, required detailed analysis of their HTML code and further concept of functional script for the automatic data collection. Due to higher demands associated with preparation processes, the realization phase of data collection was performed at the end of May and during June 2013. The result of the phase was the identification of $9260(60,95 \%)$ e-shops with customers evaluations, as well as the identification of 5934 (39,05\%) e-shops with no customers evaluations or inactive e-shops. In order to reach the aim of the research, the following evaluation criteria were identified: number of customers recommending e-shop and communication quality. The analysis of the research variables was based on the sample of 5228127 customers evaluations.

Table 1. The total number of e-shop evaluations

\begin{tabular}{|c|c|c|c|c|c|}
\hline \multirow[t]{2}{*}{ Country } & \multicolumn{2}{|c|}{ Number of reviews Number } & \multicolumn{3}{|c|}{ of e-shops Average per e-shop } \\
\hline & $\mathrm{N}$ & $\%$ & $\mathbf{N}$ & $\mathrm{N}$ & $\%$ \\
\hline Czech Republic (CZ) & 2354896 & 45,04 & 3526 & 668 & 32,66 \\
\hline Hungary $(\mathrm{HU})$ & 196536 & 3,76 & 544 & 361 & 17,65 \\
\hline
\end{tabular}




\begin{tabular}{lccccc} 
Poland (PL) & 2328700 & 44,54 & 4490 & 519 & 25,38 \\
Slovakia (SK) & 347995 & 6,66 & 700 & 497 & 24,31 \\
\hline Overall & 5228127 & 100,00 & 9260 & 2045 & 100,00 \\
\hline
\end{tabular}

Source: own elaboration

Results in Table 1 shown, that within the observed countries, Poland and the Czech Republic reached the highest portion of the total number of evaluations, $44,54 \%$ and $45,04 \%$ respectively. Comparing the average number of evaluations per observed number of e-shops, the Czech Republic dominated with 668 customers evaluation, while the lowest average was reported for Hungary at 361 customers evaluations.

\section{Results}

The ability of e-commerce subjects to communicate effectively in the online environment is one of the key drivers of customer satisfaction. On average, the most positive assessment of the communication quality received shops in Hungary (4,83 points), the most negative was recorded in Slovakia (4,53 points). The highest minimum was recorded in Czech and Hungarian shops (4 points), the lowest in Polish (1,5 points). An interesting finding is that the maximum rating for the Czech Republic was 4,9 points, for the other countries it was 5 points. The highest standard deviation was observed in data from Poland $(0,41)$, the lowest in data from the Czech Republic $(0,21)$. When conducting the evaluation of the communication quality, the most active were the customers from the Czech Republic and Poland with more than 2 300000 reviews sent in both countries.

Table 2. Results according to quality of communication

\begin{tabular}{ccccccccc}
\hline Country & N & Average & Median & Mode & MIN & MAX & VAR & SD \\
\hline CZ & 3526 & 4,62 & 4,70 & 4,70 & 4,00 & 4,90 & 0,04 & 0,21 \\
HU & 544 & 4,83 & 5,00 & 5,00 & 4,00 & 5,00 & 0,06 & 0,25 \\
PL & 4490 & 4,75 & 5,00 & 5,00 & 1,50 & 5,00 & 0,16 & 0,41 \\
SK & 700 & 4,53 & 4,60 & 4,70 & 3,20 & 5,00 & 0,05 & 0,23 \\
\hline Overall & 9260 & 4,67 & 4,70 & 5,00 & 1,50 & 5,00 & 0,10 & 0,32 \\
\hline
\end{tabular}

Source: own elaboration

Graph 1. Results according to quality of communication in box plot

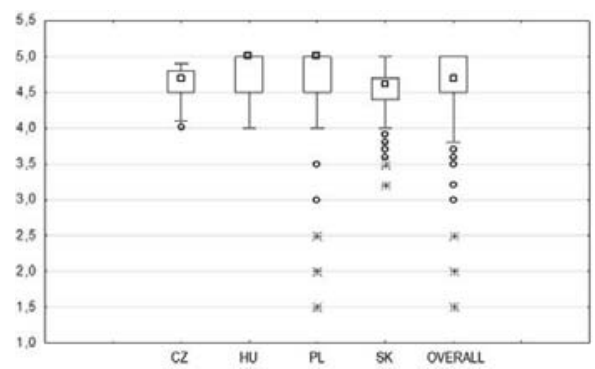

Source: own elaboration

Based on the results it can be concluded that on average the most recommended e-shops were found in the Czech Republic (95,78\%), least recommended in Poland (94,52 \%). The average recommendation rate was 95,19\%. Differences in the average recommendation were minimal. We recorded the highest minimum recommendations in Hungarian e-shops (79,00 \% - no online shop was given lower percentage of customer recommendation), the lowest in Poland $(12,00 \%)$ (minimums are shown in the Chart). The maximum for all countries was $100 \%$. Data reached the highest standard deviation in the evaluation of Polish e-shops (8,42\%), the lowest standard deviation was recorded in the recommendations of Hungarian e-shops (4,29\%). 
Table 3. Results according to willingness to recommend an e-shop in percentage

\begin{tabular}{ccccccccc}
\hline Country & N & Average & Median & Mode & MIN & MAX & VAR & SD \\
\hline CZ & 3526 & 95,78 & 98,00 & 100,00 & 41,00 & 100,00 & 0,35 & 5,95 \\
HU & 544 & 95,40 & 97,00 & 99,00 & 79,00 & 100,00 & 0,18 & 4,29 \\
PL & 4490 & 94,52 & 97,00 & 100,00 & 12,00 & 100,00 & 0,71 & 8,42 \\
SK & 700 & 95,37 & 97,00 & 100,00 & 58,00 & 100,00 & 0,27 & 5,17 \\
\hline Overall & 9260 & 95,19 & 97,00 & 100,00 & 12,00 & 100,00 & 0,50 & 7,08 \\
\hline
\end{tabular}

Source: own elaboration

Graph 2. Results according willingness to recommend an e-shop in box plot

Source: own elaboration

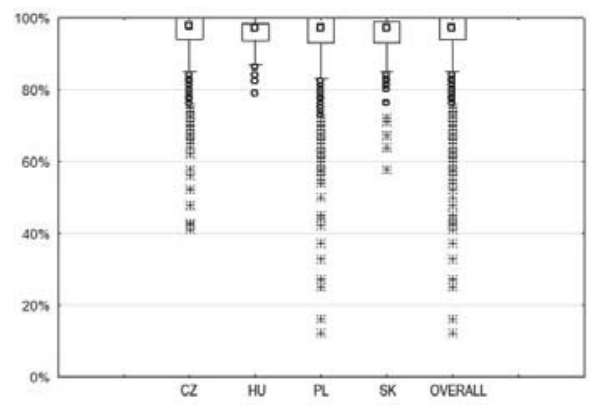

According to the research results, it is assumed that total customer willingness to recommend an e-shop is directly dependent on positive evaluation of communication quality between e-shops and customers. It is assumed that there exists a linear trend between the variables (willingness to recommend and communication quality). Pearson's correlation coefficient was used for statistical evaluation to measure the strength of a linear relationship between the paired variables.

\section{Hypotheses:}

HO: there is no linear relationship between the variables, i.e., $\rho=0$.

$\mathrm{H1}$ : there is linear relationship between the variables, i.e., $\rho \neq 0$.

Based on the graphic illustration in the Chart 3 we can conclude that in all variables evaluated there is a positive correlation dependence. As it is shown in Table 4, P value in statistical significance testing on correlation coefficient for group of selected counties is less than $a=0,01$. Therefore the null hypothesis, assuming no linear relationship between willingness to recommend and communication quality, was rejected.

Graph 3. - Scatter plot for all selected countries

Source: own elaboration

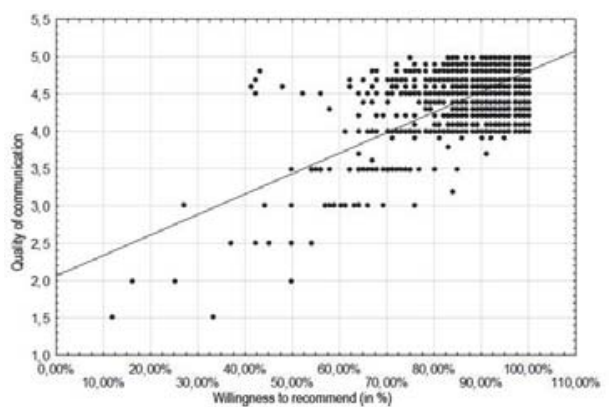


Table 4. Pearson's correlation

\begin{tabular}{|c|c|c|c|c|c|c|c|}
\hline & Average & SD & $\mathbf{r}_{(X, Y)}$ & $\mathrm{r}^{2}$ & $t$ & $p$ & $\mathrm{~N}$ \\
\hline \multicolumn{8}{|l|}{ Czech Republic } \\
\hline Willingness to recommend & 0,957841 & 0,059539 & & & & & \\
\hline Quality of communication & 4,623324 & 0,208429 & 0,042324 & 0,001791 & 2,512595 & 0,012029 & 3526 \\
\hline Willingness to recommend & 0,953952 & 0,042899 & & & & & \\
\hline $\begin{array}{l}\text { Quality of communication } \\
\text { Poland }\end{array}$ & 4,830645 & 0,246001 & 0,761126 & 0,579312 & 12,96154 & 0,00 & 544 \\
\hline Willingness to recommend & 0,945211 & 0,084227 & & & & & \\
\hline $\begin{array}{l}\text { Quality of communication } \\
\text { Slovakia }\end{array}$ & 4,751138 & 0,405425 & 0,878251 & 0,771325 & 105,3914 & 0,00 & 4490 \\
\hline Willingness to recommend & 0,953659 & 0,051652 & & & & & \\
\hline Quality of communication & 4,529147 & 0,229812 & 0,742523 & 0,551340 & 28,10975 & 0,00 & 700 \\
\hline \multicolumn{8}{|l|}{ Overall } \\
\hline Willingness to recommend & 0,951934 & 0,070847 & & & & & \\
\hline Quality of communication & 4,674235 & 0,320923 & 0,605625 & 0,366781 & 66,27022 & 0,00 & 9260 \\
\hline
\end{tabular}

Source: own elaboration

As shown in Table 4, the lowest relationship strength was identified between the variables evaluated in the Czech Republic (Rcz $\left.=0,04 ; P_{c z}=0,012029\right)$. Between the variables „recommended e-shop" and "communicaiton quality“ we recorded, positive, but only trivial correlation. The similar relationship strength in between variables was reported by respondents in Slovakia and Hungary ( $\left.r_{S K}=0,7425 ; p_{S K}=0,00 ; r_{H U}=0,7611 ; p_{H U}=0,00\right)$. According to Cohen, this relationship can be characterized as very strong. The strongest relationship was observed in Poland $\left(R_{P L}=0,8783 ; p_{P L}=\right.$ $0,00)$. When analyzing all the countries together, the correlation coefficient was calculated as in previous cases - as a large correlation (roverALL $=0,6056$; poverall $=0,00$ ). All calculated coefficients are statistically significant at the significance level $\mathrm{a}=0,05$.

\section{Conclusion}

It should be emphasized that the issue of e-commerce is a new field of knowledge that in the last decade has seen an enormous rise, as evidenced by the gradual retreat of the use of new creative ways in reaching their customers. Relatively low operating costs compared to physical shop, functional convenience of e-shops, the speed of distribution channels, the possibility of a global impact and effective promotion marketing tools represent an ideal platform for conducting business activities focused on maximization of customer satisfaction, while used properly. These facts shall be further regarded as significant from the scientific point of view. The paper presents the position of e-commerce in four Central European countries - countries of the Visegrad group. The possible measure of customer satisfaction measurement in selected areas was outlined using software automatic identification and data capture. Moreover, the preliminary study of the state of the art in Central Europe was proposed. More than 5 million observations in over $9000 \mathrm{e}$ shops showed that the customers willingness to recommend an e-shop is directly positively linked to communication with customers. These findings should help subjects of e-commerce to improve their marketing efforts in terms of communication with their customers, also help enhance their image and last but not least, have a positive impact on sales. The challenge for the future is to identify other important factors and contexts that positively influence customer satisfaction in this environment and help subjects to understand their target audience, helping them to be more successful.

\section{Research Plan, Project}

This article is one of the partial outputs of the current research grant VEGA no. 1/0145/14 entitled "Online Reputation Management (ORM) as a Tool to Increase Competitiveness of Slovak SMEs and its Utilization in Conditions of Central European Virtual Market" 


\section{References}

Adolphs, CH. \& Winkelmann, A. (2010). Personalization Research In E-Commerce: A State Of The Art Review. Journal of Electronic Commerce Research, 11(4), 326-341.

Allegro Group. (n.d.). Retrieved May 13, 2015, from http://allegrogroup.com/

Bauer, H. H., Falk, T. \& Hammerschmidt, M. (2006). eTransQual: A transaction process-based approach for capturing service quality in online shopping. Journal of Business Research, 59(7), 866-875. doi:10.1016/j.jbusres.2006.01.021

Bem A. \& Michalski, G. (2014). The financial health of hospitals. V4 countries case. In E. L'apinová \& J. Gubalová (Eds.), Sociálna ekonomika a vzdelávanie. Zborník vedeckých štúdií (pp. 1-9). Banská Bystrica: Univerzita Mateja Bela.

Dorčák, P., Pollák, F., Mudrík, M. \& Nastišin, L'. (2014). Slovak virtual market in the light of analysis of possibilities of detecting on-line reputation for selected subjects. Communications : scientific letters of the University of Žilina, 16(4), 128-132.

Gavurová, B. (2012). Source Identification of Potential Malfunction of Balanced Scorecard System and Its Influence on System Function. E+M Ekonomie a management, 15(3), 76-90.

Gburova, J. \& Matusikova, D. (2014). Tourism as important regional development factor : (on the example of the chosen region in Slovak republic). Economic annals - XXI, 9-10, 102-105.

Kwon, O. B., Kim, C. B. \& Lee, E. J. (2002). Impact of website information design factors on consumer ratings of web-based auction sites. Behaviour \& Information Technology, 21(6), 387-402.

Lee, M. C. (2009). Factors influencing the adoption of Internet banking: An integration of TAM and TPB with perceived risk and perceived benefit. Electronic Commerce Research and Applications, 8(3), 130-141.

Liao, Z. \& Cheung, M. T. (2002). Internet-based e-banking and consumer attitudes: An empirical study. Information \& Management, 39(4), 283-295.

Michalski, G. (2014). Value maximizing corporate current assets and cash management in relation to risk sensitivity. Polish firms case, Economic Computation and Economic Cybernetics Studies and Research, 48(1), 259-276

Moss, G., Gunn, R. \& Heller, J. (2006). Some men like it black, some women like it pink: Consumer implications of differences in male and female website design. Journal of Consumer Behaviour, 5(4), 328-341.

Muller, P. (2014). Analýza projevů personalizačních metód v elektronickém obchodování: diplomová práca. Praha: VŠE.

Raisova, M., Buleca, J. \& Michalski, G. (2014). Food processing firms inventory levels in hard times. In 2004-2012 Slovak, Czech and Polish enterprises case, 17th International Conference Enterprise and Competitive Environment 2014, Volume 12, pp 557-564. DOI: 10.1016/s2212-5671(14)00379-7

Ricci, F. et al. (2011). Recommender systems handbook. New York: Springer.

Rust, R. T. \& Lemon, K. N. (2001). E-service and the consumer. International Journal of Electronic Commerce, 5(3), 85-101.

Szczygiel, N., Rutkowska-podolowska, M. \& Michalski, G. (2015). Information and Communication Technologies in Healthcare: Still Innovation or Reality? Innovative and Entrepreneurial Value - creating Approach in Healthcare Management. In P. Nijkamp (Eds.), 5th Central European Conference in Regional Science Conference Proceedings Technical University of Košice (pp. 10201029). Košice: University of Košice.

Šoltés, V. \& Gavurová, B. (2013). Application of the cross impact matrix method in problematic phases of the Balanced Scorecard system in private and public sector. Journal of Applied Economic Sciences, 8(1), 99-119.

Šoltés, V. \& Gavurová, B. (2015). Modification of Performance Measurement System in the intentions of Globalization Trends. Polish Journal of Management Studies, 11(2), 160-170.

Teo, M. \& Tan, T. (2000). Factors influencing the adoption of internet banking. Journal of the Association of Information Systems, 1(1), Article 5.

Vila, N. \& Kuster, I. (2011). Consumer feelings and behaviours towards well designed websites. Information Management, 48(4-5), 166177. 